\title{
THE IMPORTANCE OF THE FOUR ENGLISH LANGUAGE SKILLS: READING, WRITING, SPEAKING, AND LISTENING IN TEACHING IRAQI LEARNERS
}

\section{HASHIM HAMEED HAMUDI ALI ${ }^{1}$}

${ }^{1}$ University of Albasra

HNSJ, 2022, 3(2); https://doi.org/10.53796/hnsj3210

\section{Published at 01/02/2022}

Accepted at 12/01/2022

\begin{abstract}
English language has not only become the most generally spoken language, but also the most important language around the world. This bold statement lies in the fact that people around the world cannot do without English. It is the major language of science, medicine, monetary interaction, and more importantly, the international language of communication. In education, therefore, English is equally important, if not more urgently important. Such acquired importance of English has made it an essential language to be learned by all non-English people in the field of education and otherwise. As a result, at the personal level more and more individuals have made sure to learn English, sometimes in addition to some other languages, to increase their chances of a better life in today's highly competitive world. At the official level too, governments across the globe have included a syllabus of English as a foreign language, sometimes as a second language, to be taught at their schools and colleges. However, mastering English would require the mastering of its four crucial skills; namely, reading, writing, speaking, and listening. Those skills are vital and the key to mastering English as a language. The current research paper is, thus, intended to investigate the importance of those four skills of English in teaching English for Iraqi learners.
\end{abstract}

Key Words: Teaching English Language, Skills; Reading, Writing, Speaking, Listening, Iraqi Learners 


\section{أهميهة هـهارات اللاغة الإنبليـزية الأربع: القراءة والكتابة والتهدث والاستمهاع في تمايم المتعلمين العراقيين}

\section{هاثم حميد حمودي علي1}

1

HNSJ, 2022, 3(2); https://doi.org/10.53796/hnsj3210

تاريخ القبول: 2022/01/12م

تاريخ النشر: 2022/02/01م

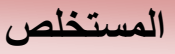

لا تعد اللغة الانجليزية الاكثر ممارسة وشيوعا في العالم فحسب، وانما تعد اللغة الاهم على مستوى العالم، ويعتمد هذا الاقرار الجريئ على حقيقة مفادها ان الناس لا يستطيعون الاستغناء عن اللغة الانجليزية في عالم اليوم، فهي لغة العلم والطب والتعاملات المالية، والاهم من هذا انها لغة التواصل العالمية. ولهذا كلة فان اللغة الانجليزية ذات اهمية ملحة بالنسبة للتعليم مما يجعلها تكتسب اهمية ايضا في باقي المجالات، وكنتيجة لذلك فعلى المستوى الثخصي يحرص الكثير من الاشخاص على تعلمها بالاضافة احيانا الى لغات اخرى لزيادة فرصهم في تحسين حياتهم في عالم اليوم القائم على التتافس الثديد، اما على المستوى الرسمي فان حكومات العالم تحرص على تدريس اللغة الانجليزية ضمن مناهجها الدراسية المدرسية والجامعية كلغة جنبية واحيانا كلغة ثانية. وبالرغم من كل هذا تضل مسالة اتقان اللغة الانجليزية امر فيه صعوبة ويعتمد على اهمية اتقان مهاراتها الاربع الاساسية المتمثلة في مهارة القراءة، الكتابة، التحدث، والاستماع. ولهذا فان الورقة البحثية الحالية تتوي تقصي ومناقشة اهمية هذه المهارات الاربع في تدريس اللغة الانجليزية للدارسين العراقيين. الكلمات المفتاحية: تدريس اللغة الانجليزية، مهارات، القراءة، الكتابة، التحدث، الاستماع، الدارسين العراقيين 


\section{Introduction and Background}

While English has progressively introduced itself as a vitally important language to the world especially at the modern times, Iraq had been introduced to English a lot earlier than some other countries in the Middle East. By the very beginnings of the nineteenth century, Iraq was a country under British rule. Britain annexed Iraq to its occupied territories, and brought with it English language to the Iraqi schools and system of education. In the beginning, English was introduced to Iraqi elementary school learners as a second language. It was a mandatory subject in the syllabus of Iraqi schools at the time. English syllabus for Iraqi schools at the time came from Britain and was prepared by British educators. By the time Iraq got its independence around the middle of the nineteenth century the status of English language gradually changed from a second language to a foreign language.

In view of that, it is true that English in Iraq has lost its status as a second language and became a foreign language, but never has it lost its value as a highly important and urgently needed language of education, science, and communication, in Iraq as anywhere else. In the contrary, English has increasingly gained in value and importance. It has become a compulsory subject in school syllabus in Iraq as it is elsewhere. Whereas the syllabus of English as a second language for Iraqi schools came from Britain, the English syllabus as a foreign language for Iraqi schools had to be "imported from Egypt and were based on the Grammar Translation Method or Classical Method," (Chalabi 76).

This high demand of English, particularly for education, has brought with it challenges and difficulties for learners. Consequently, teaching and learning English has to be introduced with new methods and strategies of teaching. Such methods and strategies have also to be evaluated and improved regularly. In Iraq, for example, the Iraqi government initiated a program for improving and refining English teaching methods and strategies in Iraqi schools and colleges. Partly sponsored by UNESCO, this program was introduced in 2011 to "various levels of learning in Iraqi schools, with the ultimate goals of enhancing English understanding among their students," (Rauf Avci n.p.).

Initially as a second language, English is usually believed to have posed more serious challenges and difficulties for learners and teachers alike. It created learning difficulties for learners at elementary as well as at higher levels of learning such as secondary schools and colleges. Those challenges occurred mainly because "teaching a second language as a second one to the native language spoken by learners is always a challenging task and its success heavily lies with the competency of the teachers as well as the effectiveness of the teaching methods," (Kareemkhan 399). Other difficulties would arise from the fact that teaching English as a second language entailed the use and practice of the language in a wide range of activities. As a second 
language, English learners were supposed to speak in English not only during class and through class activities. Learners were actually expected to use it in their daily life; in their interpersonal communication, in their official dealings, in their careers, and thus in all walks of life. The major problem in the context of Iraq was represented in the absence of necessity to speak in English as almost all people had and used Arabic as their native language in all their dealings. Nonetheless, it would have to be professed that the bigger the problem was, the greater the use and value had been. That is to say, teaching and learning English as a second language proved to have brought about more advantages and benefits in terms of knowledge, linguistic skills, and familiarity than teaching and learning it as a foreign language. In this case, the four skills of English had nearly received equal attention and care, and hence had closely developed at just about more or less the same pace.

As a foreign language, however, students have to learn English as a single subject along with many others. They, therefore, have little or no time to practice it. Their only time with the language would be in the form of certain school or college activities, and even the utility and exercise of such activities would largely depend on many factors such as the time allocated to the class, the number of students, and the teacher and his teaching methods. According to the traditional method, for instance, the principle objective of teaching English as a foreign language is to help students "read and understand English literature" (Karim 10), and to learn how to translate from a language into another. Consequently, the learners' culture received a lot less attention and focus than the native culture, (ibid). In addition, certain skills of English were overshadowed by others; speaking and listening skills were overwhelmingly eclipsed by reading and writing skills in this case.

Notwithstanding, there remains a single universal fact about English as a languagewhether secondary or foreign - that its importance and worth continued to be on the rise, not only for education purposes, but also for life and survival purposes, so to speak. No matter where you live and what language you speak, English remains the single most important, most dynamic, and highly demanded language across the world. A great many people from different geographies, with varying materialistic comfort, and of a diversity of races and ethnicities learn English and/or have a cozy familiarity with it. In fact, it is estimated that one in four people at a universal scale "can speak or at least understand English," (Crystal 14).

This is so because English is not only the language of education, or of medicine, nor is it the language of particular people or time. English has become the medium of almost all branches of human knowledge, and during our times to say the least, the language of the age. It is the language of education, of prominence, of excellence, of trade, of medicine, of diplomacy and politics, of astronomy and astrology, and all in all the language of earth and space. For that reason, mastering English, in the form of its four 
main skills, necessarily guarantees the individual a position of prominence, distinction, and ease in the academic, commercial, political, scientific, medical, and even space world. Moreover, mastering English would, at the personal level, immerse the individual with a sense of self-satisfaction and open up new vistas of entertainment and fun to such a learned individual. In view of that, the four skills of English language are not only deemed important, but also would represent the standing pillars on which English language rests, and to master English it is highly imperative to master its four skills.

\section{The Importance of the Four English Skills: Reading, Writing, Speaking, and Listening}

\section{Reading Skill}

The skill of reading is one of the key skills of English. It is vitally important for all English learners, at both school level and college level. Mastering reading skill would essentially lead to the learner's success and distinction. In terms of definition, reading is usually recognized as the effort a reader exerts to understand the hidden mysteries of a written text and to appreciate its linguistic as well as esthetic beauties and intricacies. It is a process that entails thinking for the purpose of comprehending and grasping meaning, whether that meaning is clear or vague. Without getting the meaning of a text, reading would be deemed a futile and fruitless act. In addition, it could be said that acquiring information and knowledge is not the only primary goal of reading. Getting information and knowledge is a chief aim of reading as it qualifies the learner with the "means of fostering and improving [their] knowledge of language" (Farid 128); yet, reading offers besides that a source of enjoyment and solace all at once.

Reading can also be defined as "a cognitive process in which readers use their prior knowledge and reading strategies to grasp a written text," (Mokhtari 29). In view of that, in order to get the most and best out of a written text, a learner needs to recognize the value and significance of the act of reading and to be familiar with the strategies of reading as well. To master the act of reading and become a skilled reader, a learner has to know and excel at the different reading strategies and techniques. Hence, it is highly recommended for Iraqi schools and colleges that they employ more effective teaching strategies and techniques germane to the skill of reading. In so doing, classroom activities would turn out to be more valuable and fruitful. Likewise, the full employment and activation of more effective reading strategies and techniques would trigger and stimulate the thinking faculty of learners helping them train to better understand a text and construct meaning out of it without being completely dependent on the teacher.

In the context of Iraq, many relevant studies have concluded that Iraqi learners face difficulties in terms of mastering the reading skill while studying English as a foreign language at both lower and higher levels of learning. Certain procedures have been 
recommended by such studies to go hand in hand with the reading activity and to closely observe its progress. A recent such study was conducted by Zinah Mahdi Habeeb, and Salam Hamid Abbas. This study, through designating an experimental group and another conventional group of Iraqi learners, explored the impact of "SQ3R strategy (Survey - Question - Read - Recite - Review) in improving Iraqi students' ability of reading comprehension", and concluded that "there is a statistically significant difference in EFL students' reading comprehension in favor of the experimental group," (Zinah Mahdi Habeeb 73).

Another relevant and more comprehensive study was conducted in this regard by Nabil Al-Rubaye. The study in its investigation and analysis surveyed "three reading strategy categories", which are "global strategies (GLOB), problem-solving strategies (PROB), and support strategies (SUP)," (Al-Rubaye 46). The population of the study comprised of a number of Iraqi learners studying at certain US schools. The study in its findings concluded that Iraqi learners studying at the US demonstrated both awareness of the importance of the reading skill and could utilize proper reading strategies as well. The study further asserted that Iraqi learners at US schools and colleges at both medium and high learning levels proved to be skilled readers.

Nevertheless, it seems appropriate here to emphasize the existing difference between the Iraqi context and the American context, and hence Iraqi learners in Iraq and those in the United States. The argument of the current research paper remains solidly standing in favor of the urgency and need for more focus on the reading skill and improving its techniques and strategies. Reading skill is a vital activity to learners and ordinary people alike. It is a skill that never diminishes in worth and value regardless of place and time, and one that needs nourishing through training and practice. Therefore, the argument of the current research paper could conclude that reading skill, reading comprehension, and reading techniques and strategies are significantly important and should always be enhanced.

\section{Writing Skill}

Writing is one of the chief English skills. It is a bit more important and more difficult than reading and listening. Writing is called a productive skill of the language. It requires more care, more attention, and more linguistic finesse as it actually represents a reproduction of all language skills brought together. During the act of writing, a learner, or rather a writer would certainly summon the help and accumulative knowledge and background of the skills of reading, listening, speaking, and indeed the potential of imagination as well.

In that order, it goes without saying that the writing is a significant skill that greatly influences the process of learning English. It affects the learners' ability to learn, communicate, and introduce themselves to the world. That is why writing courses and activities should occupy a considerable space in school and college syllabus. Such 
suggestion is based on true demand and need, and on recommendations advanced by various related studies. According to such studies, Iraqi learners studying English as a foreign language "show poor writing performance and weak achievement in writing courses," (Abbas 34).

The importance of the writing skill for Iraqi learners originates in the fact that "Iraqi EFL students face difficulties in writing composition, especially academic writing, which affects negatively their exam results," (Nasser 178). Iraqi learners even at university level are still prone to report writing problems in their academic achievements. The findings of several studies showed that Iraqi university students still go through a number of "difficulties of writing", and that those writing challenges emerged from various grounds such as the "students' understanding of the writing tasks, their general performance in English, as well as the instructions and methods of the teaching skills and assessment," (Mohammad 5162).

Accordingly, to write correctly and communicate your ideas well proves to be a challenging task for Iraqi learners at school as well as at college level. As a result, it is vitally important that Iraqi learners improve their writing skill in order to better deal with English language and thus increase their knowledge of it. Consequently, it is highly commended that Iraqi learners receive more attention and upgrading ways and techniques of teaching to improve their writing skill. Teachers are supposed to intensify their teaching instructions on word, sentence, and paragraph structure, conjunctions, articles, and other tense, subject-verb and vocabulary elements so that learners could master this key skill.

Mastering the writing skills mentioned above by Iraqi learners would result in enabling them to write more creatively. It is important for a learner to achieve creative writing during his learning journey because this kind of writing "is a very complicated process in which several different knowledge and skills work together simultaneously," (Dehham 128). Nevertheless, writing creatively and correctly represents a persistent challenge and obstacle in the path of all learners of English as a foreign language, Iraqi learners included. Therefore, Iraqi learners of English need to double their efforts to improve their writing skill. To do so, better familiarity with and consistent practice of the elements and style principles of academic writing are fundamental prerequisites to improve and eventually master the writing skill. In the context of learning English as a foreign language, English writing skill is seen by many to be the key skill to achieve academic success and distinction. In that view, the more the practice is, the better the writing skill will be. It is commonly believed in the midst of English language teachers and learners alike that the "better usage of English language needs more practice, deep understanding, and massive comprehension of the target language vocabulary", because "getting the exact meaning of each word helps in bettering up the students' performance in writing," (Aajami 185). 


\section{Speaking Skill}

Speaking is another productive skill of English language. It is as equally important as the writing skill, and perhaps more important. Just like writing as it represents the accumulation of knowledge and background of the remaining skills combined, speaking skill would also stand for the same, plus being the indispensable bridge of understanding and valuable communication. Without an effective and proficient speaking skill, communication and understanding would be lacking, and the alternative would most possibly and in most cases be misunderstanding and confusion. Therefore, learners of English should make sure to master speaking in order to communicate clearly, fluently, and productively. The skill of speaking could also serve as a medium of imparting ideas, information, and knowledge, and in return receiving not only senses and meanings out of them, but also attitudes and impressions. Similarly, speaking is an act and once someone speaks, he/she "adjusts the way he speaks (or writes) according to the situation he is in, the purposes which motivates him and the relationship between him and the person he is addressing," (Geoffrey Broughton et n.p.).

However, Iraqi learners - just like Arab and all other foreign learners of Englishshow signs, and suffer from a sense of anxiety. This anxious attitude towards English is generated due according to certain studies to the "nature of speaking which includes strange accent, speed of speech, and limited time given; speaking activities such as long conversation, individual conversation, group conversation, and speaking topics and telling a story, low level of students' English proficiency; and finally, the classroom environment," (Saad 15). That anxiety with relation to speaking English would then bring about a lack or absence of intelligibility.

In a similar perspective, foreign learners, Iraqis and otherwise, would face a difficulty communicating with native speakers of English as they speak the language - to varying degrees - in an unintelligible way, which leads to the loss of English communicative value as a language. In the context of Iraq, Iraqi learners have been reported to be quite intelligible in their speech performance of English. Yet, they showed "variations of intelligibility due to foreign accent and accent familiarity," (Younus 186). Still, there exist other estimations that suggest that "the majority of Iraqi EFL students lack the opportunity to use the language especially with native speakers in real life communication," (Yuen Chee Keong et 158). This reality of foreign learners studying English has led English teachers and concerned bodies to look for ways, methods, and techniques to overcome such obstacles, improve the speaking attitude of learners in an effort to help them eventually master English-speaking skill. Such helping aspects would vary from audio and video tool, to allowing more learners' involvement in the learning process in the form of pair and group work, and role-play, to name only some, which in turn have demonstrated "a significant improvement in speaking skill," (Krebt 863). 
In that order, mastering the speaking skill of English is advised as a priority for Iraqi learners of English. Additionally, learners of English as a foreign language, as the case in Iraq, tend usually to assess and weigh their language learning achievement and brilliance in terms of how fluently, effectively, and proficiently they speak the language and "how they feel about it," (Jack 10). Besides, improving and perfecting English-speaking skill in and outside the classroom paves the way for more chances of success in studying as well as in real life situations and encounters. Moreover, speaking English fluently and proficiently in class activities and in real life situations helps learners overcome the sense of anxiety that frequently accompanies speaking a foreign language, and hence relieves them of the pressure and burden of too much selfconsciousness, (Harmer 123). In the context of education, practicing the speaking skill by learners helps in providing English teachers with a more reliable and solid feedback about their learners and the learning process as a whole.

Once English language learners could express themselves easily and clearly, convey their ideas intelligibly, and communicate information effectively, it could then be determined that they have mastered the skill of speaking. Speaking as a language skill is then deemed purposeful and fitting. Once it reaches the stage of fruition, speaking skill carries along with it further implications because its success "is measured not only in the functional effectiveness of language, but also in terms of the acceptability of the forms that are used," (Wood 21). Summing up, speaking skill is perceived to be residing among the more important language skills, if not the most important one. The need to practice it leads to mastering it, which in turn enables learners become better learners, better communicators, and even better human beings.

\section{Listening Skill}

Listening is the fourth and last of the four English language skills. It is still a correspondingly important skill. Some might tend to underestimate and undervalue the significance and influence of the listening skill. Nonetheless, listening represents a vitally important skill in the process of learning English as a foreign language. It is true that some learners and/or people might not be able to feel and gauge the benefits of listening to the improvement of English learning. This is so because the impact of listening on improving the learner's proficiency in the language takes place at a lot deeper layers of the individual's conscious and unconscious mind. When a leaner is exposed to longer hours of listening sessions, they can sense immediate and noticeable improvement once they start speaking.

The effects of listening reflects itself mostly in the speaking skill and in the other skills, with lesser degrees of influence though. The learner's potential to speak more fluently, read with more speed and precision, and to write more creatively and more smoothly are observed to be, to a considerable extent, consequential outcomes of listening.

In oral communication, listening would surprise many of us to take top element on the 
list of factors. Yet, an illustration for this point would be through reflecting upon how much time a baby and an adult spend talking and how much of the same time they spend listening. It would not come as a surprise to realize that babies spend almost all their time listening rather than speaking. In actuality, it is precisely this time babies spend listening that qualifies for their ability to acquire a language in the first place. However, it would most probably surprise us all to understand that even adult people spend the majority of their time listening rather than speaking as they spend " $42 \%$ to $60 \%$ of their time on listening," (Rankin 629). Such startling findings demonstrate the major role that listening skill plays in our other skills, mainly speaking skill.

Other people argue further that listening skill is the most important of all language skills. The case of newly born babies is again brought for supporting this assumption stating that listening is the very "first skill babies develop", even at the stage of pregnancy as a baby "listens to mother's voice", and "can distinguish it among other voices," (Purdy 34).

Important as it really is, listening skill still cannot be embraced without difficulties and obstructing factors. All learners of English as a foreign language would most definitely report facing certain challenges and difficulties in listening to English. Certain studies conducted in this regard concluded that Iraqi English "language learners' listening skill level does not correspond to international requirements", and that "listening anxiety constitutes a real problem," (Doghonadze 2002).

There is, hence, a true and urgent need to improve listening skill for Iraqi learners. This need stems from the fact that listening is a chief skill of English language. Besides, it has been shown through some studies that "improving listening skills of the learners provides motivation and inspiration depending on the interaction between teacher and learner, which is the result of Pygmalion Effect, in the process of acquiring language," (ibid 1999). Accordingly, there has been constant attempts to come up with particular ways and assisting means to help enhance and improve the listening skill for learners of English language. Such means would range from providing audio and visual helping tools to modifying class activities, to, at certain times, the exposure of learners to the native environment of English language. One such tool, for instance, would be particular listening strategy instruction; a method that proved to have "generally a positive impact on learners' listening comprehension and metacognitive awareness of strategy use," (Al-Shammari 1). Some other strategies would amalgamate both education and entertainment. That is to say, teaching listening skill, for illustration, would not be confined to information and educational purposes only. A listening passage would be accompanied with cultural information or with games or funny stories, for example. That aspect in teaching listening skill-or any other language skill - is called edutainment. This new development in teaching English as a foreign language has proved to be "useful for developing learners' listening comprehension of 
English language," (Wisam Qasim Mohammed et. al 498).

All in all, it could convincingly be settled that no act of language can be possible without listening. A baby born deaf loses the ability to speak on the account that he is deprived of the activity and skill of listening. Besides, the relationship between listening skill or faculty and all other language skills seems to be ontological and interdependent.

\section{Concluding Remarks}

The current research paper has been set out to discuss and demonstrate the importance of the four different skills of English language. The paper began by introducing a brief background of the history and status of English language in Iraq; first as a second language, then as a foreign language. The significance and necessity of englisg in today's world has been investigated, too. The present research paper has then shown how important those different skills are in the process of learning English in the context of Iraq. The argument has illustrated that in the case of Iraqi learners-as well as any other foreign learners of the language - studying English as a foreign language, mastering the different skills of the language is the doorway to mastering the language and to success. In addition, the four skills of English have been shown to be virtually equally significant in the whole process of learning English for Iraqi and other learners for that matter.

\section{References}

Aajami, R. F. "Applying Cognitive Linguistics to Enhance the Semantics of English." International Journal of English Linguistics (2018): 185-192. PDF.

Abbas, Salam Hamid. "Writing Apprehension and Performance of Iraqi EFL Students According to their Academic Locus of Control Orientation." International Journal of English Language Teaching (2016): 34-48. PDF.

Al-Rubaye, Nabil. Reported Reading Strategies of Iraqi Graduate Students Studying in US Universities. MA Thesis. Oklahoma: Oklahoma State University, 2012. PDF.

Al-Shammari, Hussein Ghanim. "The Impact of Strategy Instruction on Iraqi EFL Learners' Listening Comprehension and Metacognitive Strategy Use." MEXTESOL Journal (2020): 1-12. PDF.

Chalabi, S. A. al. Teaching English as a foreign language in Iraq with emphasis on the in-service training of secondary schools teachers of English. Baghdad: Dar Al-Jahidh Press, 1976. PDF. Crystal, D. "Emerging Englishes ." English Teaching Professional (2000): 3-16. PDF. 
Dehham, Sabeeha Hamza. "Developing Iraqi EFL School Students' Performance in Creative Writing Skills Through Focus Strategy." International Journal of Language and Linguistics (2020): 128-134. PDF.

Doghonadze, Rauf Avci \& Natela. "The Challenges of Teaching EFL Listening in Iraqi (Kurdistan Region) Universities." Universal Journal of Educational Research (2017): 1995-2004. PDF.

Farid, M. Akbar and G. Language Teaching Theories, Approaches, Methods, and Skills. N. P.: Azad University, 2012. PDF.

Geoffrey Broughton et, al. Teaching English as a Foreign Language. New York: Routledge , 1980. Print.

Harmer, Jeremy. How to Teach English. UK: Cambridge, 2007. Print.

Jack, Richard C. Teaching and Listening From Theory to Practice. Cambridge: Cambridge University Press, 2008. Print.

Kareemkhan, Dariyan Dhaher. "ESL Teaching Strategies in Iraqi Public Schools." International Journal of Scientific \& Engineering Research (2018): 393-406. PDF.

Karim, Mahdi Sofi. English Language Teaching in the Kurdistan Region of Iraq . MA Thesis. Webster: Webster University, 2015. PDF.

Krebt, Dhea Mizhir. "The Effectiveness of Role Play Techniques in Teaching Speaking for EFL College Students." Journal of Language Teaching and Research (2017): 863-870. PDF.

Mohammad, Awham Rasheed. "Difficulties of Writing in English Encountered by Iraqi EFL Learners at University Level." Journal of Critical Reviews (2020): 5157-5163. PDF.

Mokhtari, R. Sheorey \& K. "Differences in the Metacognitive Awareness of Reading Strategies among Native and non-Native Readers ." System (2001): 431-449. PDF.

Nasser, Sura Muttlak. "Iraqi EFL Students’ Difficulties in Writing Composition: An Experimental Study (University of Baghdad)." International Journal of English Linguistics (2019): 178184. PDF.

Purdy, M. What is Listening? New York: NY University Press, 1997. PDF.

Rankin, P. T. "The importance of listening ability." The English Journal (1928): 623-630. PDF. 
Rauf Avci, \& Natela Doghonadze. The Challenges of Teaching EFL Listening in Iraqi Universities. N. P.: n. p., 2017. PDF.

Saad, Noor Sabah Naeem \& Norma. "Exploring the Causes of Speaking Anxiety of Iraqi EFL Students." IOSR Journal of Research \& Method in Education (2020): 13-22. PDF.

Wisam Qasim Mohammed et. al. "Using Edutainment in Developing Iraqi EFL 4th Preparatory School Students' Performance in Listening Comprehension." Ilkogretim Online - Elementary Education Online (2020): 491-499. PDF.

Wood, William Little. Communicative Language Teaching. Cambridge : Cambridge University Press, 2004. Print.

Younus, Majid Rasim. Speech Intelligibility: A Study of Iraqi EFL Learners'Accented English. Ph.

D. Thesis. London: London Metropolitan University, 2020. PDF.

Yuen Chee Keong et, al. "Speaking Competence of Iraqi EFL Undergraduates of Garmiyan University." International Journal of Education and Research (2015): 157-170. PDF.

Zinah Mahdi Habeeb, Salam Hamid Abbas. "The Effectiveness of SQ3R Strategy in Promoting Iraqi EFL Students' Reading Comprehension." International Journal of Research in Social Sciences and Humanities (2018): 73-88. PDF. 